\title{
Temporary Agency Worker Organizing in an Era of Contingent Employment
}

\author{
Aziz Choudry, McGill University, Montreal, Canada \\ Mostafa Henaway, Immigrant Workers Centre, Montreal, Canada
}

\begin{abstract}
This article discusses labour organizing among racialized immigrants and migrants working for temporary labour recruitment agencies in Montreal. It discusses building worker agency, leadership, an independent organization of temporary agency workers and broader campaigns against agency industry practices, often characterized by low wages, poor working conditions, and labour law violations. The article contextualizes these conditions and workers' struggles within broader historical and contemporary trends in national and global labour, the transformation of work, immigration and economic policymaking at a time of capitalist crisis and austerity. It also highlights the significance of knowledge produced by migrant and racialized immigrant workers as a key resource for strategies for resistance against agency exploitation.
\end{abstract}

\section{KEYWORDS}

Canada, immigrant workers, labour organizing, migrant workers, temporary labour agencies

\section{Introduction: Temporary Agency Industry and Worker Exploitation}

Worldwide, migrant workers and racialized immigrant workers have long provided pools of 'cheap' labour to be exploited. This labour is pivotal to the functioning of many societies. Richmond (1994: 204) describes the rise of 'a system of global apartheid based on discrimination against migrants and refugees from poorer developing countries'. A global (often Western-) educated elite is relatively mobile, but the overwhelming majority are temporary, non-status, exploitable, and often underground.

Today, in many countries, border controls increasingly manage flows of largely temporary migrant workers - a rotating-door labour market geared to just-in-time production. Kundnani (2007: 145), reflecting on British immigration history, writes that instead of the idea of the postSecond World War reserve army of manual workers, 'the new post-industrial migrant workforce was characterized by several distinct streams - reserve regiments of labour - each adapted to the specific 
needs of different sectors of the economy. The intricacies of the system would be kept subject to constant review and adjustment, so that the numbers, character and entitlements of workers entering the economy under different schemes could be changed as necessary. Each of these various routes provided employers with a different package of exploitation...'.

One 'package of exploitation' impacting migrant and racialized immigrant workers exists in the temporary labour (temp) agency sector. Van Arsdale (2013: 107) suggests that outsourcing labour by the US temp agency industry produces poverty for millions and stagnating wages for all workers. He contends that ' $[\mathrm{t}]$ emporary help is becoming the great stabilizer of modern capitalism. It will consistently grow as the economy expands over time, encountering occasional downturns as recessions are encountered. Each recession will lead to greater dependency on staffing, as companies transition to hiring temporary workers to sustain economic downturns and labor expenses'.

There is growing international scholarly interest in temp agency expansion in the context of labour deregulation and flexibilization and economic restructuring. For example, studies have discussed temp agency labour in Canada (Cranford, Vosko and Zucewich 2003), Japan (Suzuki 2008), New Zealand (Casey and Alach 2004), the USA (Peck and Theodore 2002, Theodore and Peck 2002, Hatton 2011), Italy (Degiuli and Kollmeyer 2007), and the UK (Forde 2001). Some authors focus on connections between immigration status, race and agency work (Vosko 2000, Fuller and Vosko 2008, Gonos and Martino 2011). Women, recent immigrants and youth tend to be overrepresented in agency jobs. Agencies range from global corporations like Manpower, Randstad, Kelly and Adecco to small local labour agents.

Agency work is growing rapidly in Quebec. This article discusses organizing against exploitative practices of the agency industry, especially Montreal's Immigrant Workers Centre (IWC) and Temporary Agency Workers Association (TAWA). The IWC, like many workers centres in North America (Fine 2006), stands at a juncture between traditions of labour unions and community organizing. One author is an academic and IWC board member; the other is an IWC organizer. We write from a tradition of engaged scholarship which builds upon knowledge production and learning in social movements, drawing from the organizing experiences of IWC organizers (Choudry and Henaway 2012, Henaway 2012), from which much of our information derives. We illustrate how knowledge produced by workers themselves is a vital resource for analysis, education and action for mapping labour precarity and documenting practices of agencies and businesses which use them.

There is ample documentation of how racialized new immigrants are discriminated against in the labour market and frequently pushed into temporary work upon arrival (Vosko 2000; Galabuzi 2006; Zaman 2006, 2012; Choudry, Hanley, Jordan, Shragge and Stiegman 2009; Calugay, Henaway 2011; Choudry and Henaway 2012). Agencies often justify practices like paying low wages and providing no benefits, arguing that recent immigrants receive valuable 'Canadian experience' (Vosko 2000, Cranford and Ladd 2003). For Vosko (2000: 190), '[j]ust as officials argued that the industry represented an ideal labour force re-entry vehicle for women absent from the labour force while raising children in the late 1960s and early 1970s, they now claim that temporary help work is a suitable means for immigrants to gain experience and exposure in the Canadian market'. New arrivals are often under pressure to find a way to make ends meet, but claims that temping can help 
someone gain a foothold in the labour market and stable permanent work are questionable. Vidal and Tigges (2009) hold that the agency industry has moved from a 'reactive' use of temps as replacements for absent employees, or as purely supplemental staff during peak periods, to the 'systematic' use of temps, in which entire job clusters and industries are staffed with agency workers indefinitely. Hatton (2011) notes that permanent workers are replaced with 'permanent temporaries', shifting workers to agency payrolls, with attendant employer savings and the avoidance of obligations towards workers, and broader, deeper impacts on labour and the nature of work itself. Workers are on permanent probation, can be dismissed at any time, for any reason, without benefits. Thus, for many, the prevailing trend is not movement from temporary to permanent jobs, but the opposite. Vosko (2000: 193) notes that many recent immigrant workers felt trapped in precarious agency work where the racialized division of labour 'is a product of two overtly racist practices that reveal the ideological nature of the industry's promise of "Canadian experience": namely, placing workers of the same background together intentionally, and thereby perpetuating segmentation, and refusing to provide references to recent immigrants'. She draws parallels between today's agencies and nineteenth century padrones - labour agents who profited from matching transient migrant workers with jobs and controlled much of their lives.

Between 1993-2008, the number of registered agencies in Canada increased by 325 percent from 1191 to 5077 (not including many unregistered agencies) (Statistics Canada 2010). Start-up costs are modest: agencies do not usually need a license to operate. By 2008 over 1200 agencies operated in Quebec, in virtually all sectors, including office work, cleaning, construction, healthcare, manufacturing, and agriculture. An earlier Statistics Canada report found the earnings gap between permanent and contract workers was about 13 percent, while between a permanent and casual worker the gap was about 34 percent (Galarneau 2005). The disparity persists even after adjustments for demographic differences like education levels, immigration status and gender.

\section{Conditions of Agency Workers}

Freeman and Gonos (2005: 305) suggest that besides producing subservience and abuse of workers, 'the negotiating activities of staffing agencies impede workers' ability to engage in concerted activity to effectuate meaningful bargaining over the terms and conditions of their employment'. For them, agencies' 'substantive bargaining relationship with the user employer is one of collusion with that employer to minimize workers' wages and benefits and to maximize profits' (307). Vosko (2000, 2008) dubs dominant approaches to theorizing the labour market as 'SER-centric' (SER = standard employment relationship). She argues that the SER (based on the pillars of a bilateral employment relationship between employee and employer, standardized working time, continuous employment) is not the norm for many workers and therefore SER-centric approaches. There is no direct employment relationship with and supervision by a single employer on their premises but rather a triangular one between worker, agency and client company. Several scholars suggest that as formulated, labour law and labour standards are poorly suited and inadequate to address the increased presence and significance of temp work (Vosko 2000, 2008, 2010; Freeman and Gonos 
2005). Vosko (2000) and others warn of the potential of the temp relationship to become an employment norm for a wider segment of society.

In Montreal, there are two major types of agencies - firstly, larger, registered agencies, secondly, unregulated 'fly-by-nights' which mainly operate outside of the official labour market and are often hard to track down. Fly-by-night agencies often recruit desperate workers without legal status and/or who are unable to find stable work. They operate mainly in the agricultural sector, paying cash, often below minimum wage, with neither health and safety coverage nor basic respect for minimum labour standards. The IWC also encountered a case where a popular coffee shop chain purchased sandwiches through a subcontractor, which hired such agency workers. Six Mexican refugee claimants, sandwich-makers paid below minimum wage, were owed almost three months in unpaid wages. The subcontractor blamed the agency, which blamed the subcontractor. Workers felt unable to complain lest it impact their refugee claims because they were not allowed to work legally.

A critical moment in creating public awareness and leadership building around agency work came in October 2010 with the IWC's collaboration with an investigative documentary by Radio Canada. Journalists posing as new immigrants documented practices of fly-by-nights, working for cash through agencies in chicken-processing plants (Radio Canada 2010). One journalist wore a hidden camera when applying to agencies specializing in placing immigrants who speak no English or French. Assigned to Montreal chicken factories, they worked alongside regular staff. 'No one ever asked me for a single piece of ID. Not even my ... [health] card. If I'd had a workplace accident, what would have happened then? Who would have been responsible for my care?', recalled undercover journalist Martin Movilla, originally from Colombia. They were expected to work long shifts, up to nine hours at a time, sometimes with only one 15 -minute break, for between $\$ 6.50$ and $\$ 8.00$ per hour. Agencies understand how to leverage workers' immigration status to provide cheap labour. The most worrisome practices are adopted by fraudulent agencies who recruit vulnerable individuals, such as new immigrants unaware of their rights and in dire need of income. The documentary led to other media discussing agency work and precarity, adding pressure on Quebec's Minister of Labour to address concerns raised. Such coverage served as a critical education tool for a broader audience while giving voice to the first group of agency workers with whom the centre had built relationships.

Among agency workers, there are wide differences. Broadly, the IWC sees three categories of workers whose precarity and vulnerability is exploited in particular, though overlapping, ways, through two types of agencies (see table). 
Table 1: Immigration status, agency type and key issues

\begin{tabular}{|c|c|c|}
\hline $\begin{array}{l}\text { TYPE OF AGENCY (and key } \\
\text { issues) } \\
\text { IMMIGRATION STATUS }\end{array}$ & $\begin{array}{c}\text { LARGER, REGISTERED } \\
\text { AGENCIES } \\
\text { (e.g. distribution centres, } \\
\text { warehouses, service work) }\end{array}$ & $\begin{array}{l}\text { FLY-BY-NIGHT AGENCIES } \\
\text { (e.g. food processing, } \\
\text { agricultural work, meat } \\
\text { packing, cleaning) }\end{array}$ \\
\hline NON-STATUS & & $\begin{array}{l}\text {-Paid cash } \\
\text {-Issues of non-payment } \\
\text {-No CSST in case of workplace } \\
\text { accidents } \\
\text {-No basic labour rights } \\
\text { (holiday, vacation, minimum } \\
\text { wage) } \\
\text {-Difficult to organize }\end{array}$ \\
\hline REFUGEE CLAIMANTS & & $\begin{array}{l}\text {-Issues of non-payment } \\
\text {-Forced to work under the table } \\
\text {-No work permit }\end{array}$ \\
\hline $\begin{array}{l}\text { PERMANENT } \\
\text { RESIDENTS/CITIZENS }\end{array}$ & $\begin{array}{l}\text {-Discrimination based on race, } \\
\text { and immigration } \\
\text {-Issues of seniority } \\
\text {-Lack of job security } \\
\text {-Lack of CSST enforcement - } \\
\text { inadequate provision of safety } \\
\text { equipment for workers } \\
\text {-Fear of losing job } \\
\text {-Difficult to unionize }\end{array}$ & $\begin{array}{l}\text {-Long term health care } \\
\text { agencies/ Issues of non- } \\
\text { payment } \\
\text {-Issues of lack of job security, } \\
\text { seniority } \\
\text {-Lack of CSST enforcement } \\
\text {-No vacation pay, over-time }\end{array}$ \\
\hline
\end{tabular}

Source: Authors

Firstly, the most exploitable category of agency worker comprises those without status. Unable to work legally, they are forced to find any form of work, such as through small fly-by-night agencies, because they have no access to social assistance. These agencies rely mainly on networks within specific immigrant communities, paying cash for work in food processing, cleaning, and agriculture. The second category of worker comprises refugee claimants on social assistance. They cannot work legally, but for people with families, social assistance is insufficient to live on and well under the poverty line. Many refugee claimants work for fly-by-night agencies in food production for cash. Employers and agencies know that they will not make formal complaints because they are on social assistance and particularly vulnerable. 
The third category of agency workers that IWC works with comprises permanent residents and citizens who suffer institutional racism and discrimination. Meaningful employment is difficult for them because their education and qualifications are not recognized, or they may have been laid off from more stable manufacturing or service sector jobs. Many - especially those with limited language skills or without newer skills needed for the labour force - are forced into agency work. Systemic racism tends to push racialized workers into lower-paid, lower status jobs with lower rates of unionization and greater precarity than white workers in Canada (Galabuzi 2006; see also Chicha [2009] on systemic discrimination and employment in Quebec). In a survey for Le Commission des normes du travail (CNT) (CNT 2012) (Quebec's labour standards board) 90 percent of 1000 agency workers interviewed reported one or more labour standards violations.

\section{Challenges of Agency Worker Organizing}

In thinking through challenges for organizing agency workers in Quebec, it is helpful to look at other contexts. Although the conditions of temporary work have been similar in nature, organizing strategies have been quite different in Japan, the US, and Canada. In Japan (Kojima 2010, Suzuki 2008), organized labour and more radical organizers have worked through community unions which can be geographically or identity-based. This strategy is possible because under union recognition procedures of Japanese labour law, an individual worker, or group of workers, including those who form a minority in their workplaces, can form a union with the right to engage in collective bargaining with management of their respective firms. Such a strategy, incorporating individual agency workers into a collective structure, facilitates their collective identity as workers. This Japanese approach is based on the model of individual membership in community unions that have collective bargaining power. Canadian labour legislation does not allow for individual membership in unions, thus requiring different forms of organizing agency workers.

While US workers centres utilize many strategies, the Latino Union of Chicago (founded in 2004) offers an interesting perspective on building capacity for social and economic change. It has similar organizing strategies to other worker centres, including the IWC, in fundamental programs such as leadership development, addressing policy changes, and links to the broader labour and immigrant rights movement. The Latino Union focuses mainly on day labour, and created its own hiring hall as a source of collective power (Latino Union of Chicago, n.d). Freeman and Gonos (2005) and Gonos and Martino (2011) discuss the union hiring hall strategy and the potential for such a strategy to improve conditions for Latino immigrant workers who work for agencies contracting to warehouse and distribution centres in New Jersey. In some US contexts, unions and other labour organizations have used hiring halls to fight the abuses of company-controlled shapeups and replace them with a more equitable process of allocating work.

\section{Organizations}

Agency workers' jobs in and around Montreal are diverse, but reflect growing precarity. One IWC ally, the collective Dignidad Migrante, works with Latina/Latino migrants on local migration 
and work issues, including agency exploitation. Another ally, PINAY, has dealt with agencies around issues faced by migrant Filipina domestic workers under Canada's Live-in Caregiver program (LCP). LCP workers frequently pay large recruitment fees to agencies to find employers. Temporary foreign workers arriving under the federal low-skilled pilot project sometimes come through agencies abroad which charge enormous recruitment fees of up to $\$ 10,000$ (NUPGE 2007). Many migrant workers have already been exploited by recruiting agencies in their countries of origin in order to get work overseas and are under great pressure to pay back debts incurred.

In 2009, the IWC began outreach to agency workers, particularly Spanish speakers, working for fly-by-night agencies. One group comprised new immigrants from Mexico working for cash under the table, below minimum wage, in a food processing plant. The agency disappeared, leaving them without wages, or access to unemployment insurance. Yet under existing labour laws the company sourcing workers through the agency was not responsible for the workers' problems, yet created and managed the work environment. The IWC challenged these conditions firstly through a public campaign to address the systemic issues of placement agencies. The second focused on mobilizing workers themselves to build their capacity to lead such a campaign and challenge workplace conditions. The IWC has attempted to build a campaign not just based in an immediate fight around one workplace, but rather one that could result in a long term campaign relevant to the working class as a whole. It wanted to challenge conditions common to different workplaces and communities, and change the conditions of all workers impacted, those with immigration status and without, and including unionized workers. A major goal has been to strategically collectivize isolated and transient agency workers. One means to do this has been the effort to create collective strategies amongst particular communities, organizing amongst Spanish-speaking workers who share many similar work experiences in slaughter houses, food processing, cleaning and day labour. For many, the primary issue is immigration and working with fly-by-night agencies. Organizing strives to create a common narrative among workers to break the isolation and fear of the consequences of complaining about working conditions, and build collective capacity and solidarity.

Given the spectrum of agency workers' situations, what was needed was an umbrella organization flexible enough to address the particular issues faced by a wide range of agency workers and to build a larger movement that could change both policy and act like an independent union run for and by agency workers. Thus the Temporary Agency Workers Association (TAWA) was founded in 2011. Ultimately, a broad organizing vision would benefit diverse types of workers, and would decrease the tools that employers and companies can use against workers. A goal was to build more workplace fight-backs locally, while building real leadership amongst migrant and immigrant workers. Concretely, this initiative meant understanding the workers' situations and helping forge relationships amongst them. This has led to a deeper understanding of how most work has been changing drastically, governed by a form of austerity and outsourcing which has been effectively able to undermine the gains of workers over the past thirty years, advanced on other fronts by public sector cuts and free trade and investment policies.

The TAWA demands respect of basic labour rights and better standards of decent work for all agency workers, regardless of immigration status, and aims to support workers on an individual and collective level. The TAWA works to bring these non-unionized workers together to challenge 
individual workplace problems and working conditions for agency workers through solidarity. Agency workers are uniting, building their organization to defend their rights, providing services and building a community union to meet the real needs of immigrant workers with low wages. The group also seeks to raise awareness on this issue, to pressure the government to take concrete steps to protect the rights of all workers. The TAWA also supports justice movements for the regularization of migrants of all persons without status.

One example of agency worker exploitation which the IWC and the TAWA have confronted concerns Dollarama, Canada's fastest growing chain of dollar stores. Dollarama's major Montreal distribution warehouse is staffed by over 500 mainly immigrant workers, many of whom are from North Africa. Most workers are employed by a registered Montreal-based agency, ThomsonTremblay. Some are permanent residents or citizens, others are refugee claimants. Even workers who have been there for three years were unable to be hired directly by Dollarama. When the IWC attempted to have a white McGill graduate volunteer 'salt' (i.e. attempt to be hired), the agency offered him office work because he looked 'too good' to work in the factory. Conversely, a Haitian worker, a fluently bilingual accountant, who had practiced accountancy in Montreal, had repeatedly asked for office work commensurate to his training, yet continued only to be offered warehouse work. Outreach and consistency are pillars of the IWC's work in reaching new layers of people. After leafleting for over a month outside the warehouse, the IWC began to make contact with workers, and gain an understanding of a host of issues related to agency work. One group of African workers related their work experience to slavery, and became curious about their rights. One worker said, 'Certainly one could compare it to slavery, and I've been able to understand in my time here that just by an individual's skin colour, when I go to the placement agency, there's work for those that are black, and there's work for those that are white', adding that he lost jobs to white Quebecois people despite advanced qualifications (Immigrant Workers Centre 2012). This has been the IWC's starting point in building a longer-term campaign and implementing lessons from previous struggles.

The TAWA focuses on outreach in locations where day labourers are picked up and dropped off, and works with other community groups in the Latin American community where many workers are recruited to work for fly-by-night agencies. It also does outreach near distribution centres, such as Dollarama and Davids Tea, where workers are contracted through more established agencies. This includes handing out informational flyers near agencies in key neighbourhoods at periods when workers are getting paid. The work includes holding actions for theft of wages, in the case of some fly-by-night agencies and, for workers in larger agencies, organizing workshops around health and safety rights.

At workshops, Dollarama workers expressed frustration at their workplace conditions, particularly regarding safety concerns. One Dollarama worker described conditions at the distribution warehouse. 'There are a lot of people who bump into each other because everyone is on guard, everyone is stressed because everyone wants to reach their quota'. The pace of work has also become dangerous. The worker continued: 'I was surprised that in an industrialized country like Canada, you could have places where people work more than machines'. This worker's job involved lifting boxes all day to build massive pallets of merchandise. His daily quota was 23 pallets. 'To do 
23 pallets a day, you have to do a lot of heavy lifting, and we don't have time to rest, so it's physical, and the place is very noisy, there's a lot of dust' (Immigrant Workers Centre 2012).

Workers also criticized agencies' discriminatory practices in hiring workers mainly from Africa and Haiti regardless of professional experience and desire to be placed in skilled positions in offices, given that the agencies place them in low-wage factory work in different companies. The TAWA ran a workshop series in Spanish in collaboration with Dignidad Migrante, which strengthened relationships with Spanish-speaking agency workers. Monthly workshops with lawyers, CNT representatives, and labour organizers have addressed issues such as CSST (la Commission de la santé et de la sécurité du travail - workplace health and safety) and CNT coverage for agency workers, employment insurance and welfare regulations. Further outreach is happening through community/multilingual radio stations to reach other agency workers. One Mexican migrant worker recounted his experiences of fly by night agencies in this way:

'I started working for agencies in February 2008, I have had different jobs, cleaning trays in a bakery. Another job was a cleaning job clearing ice and snow. The degree of safety I have had is nil. Let's say the job I had clearing snow on roofs with ice, no cleats, no boots, no helmets and harnesses. The workers from the company had all of these things. Obviously we don't have any rights: we are basically pawns in the system until we can no longer work the machines. ... I was paid $\$ 9.00$ an hour when I saw a contract that stipulated the person should be paid $\$ 17.00$ an hour. Also they will pay a person $\$ 9.00$ an hour for one position that should be done by 2 workers'. [Quebec minimum wage is $\$ 10.15$ ] (Immigrant Workers Centre 2012)

In 2011, Au bas de l'échelle, a Montreal organization which advocates on issues related to working in precarious situations, published research documenting how agencies undermine labour standards and working conditions and contribute to the growth of precarious labour (Au bas de l'échelle 2011). The findings are typical of research on working conditions for agency workers in other contexts. They include the general poor working conditions, unequal treatment of workers in the same workplace (i.e., employees and temp agency workers), systematic infractions of the labour code by some agencies, abusive clauses in the contract signed between agency and workers, the lack of employer responsibilities, and the higher level of accidents among agency workers. Some employers have also established their own agencies, which hire specifically for them. One strategy for agencies is to operate through more than one registered company and move workers from one agency to the other to avoid paying overtime.

All of these practices are highly problematic. But the question of the employer not being responsible for violations of workers' rights has major implications for recourse for workers. Vosko (2000: 154) suggests that the temp industry is selling 'a new type of employment relationship to its customers, one that allows both the agency and the customer to adopt a range of distancing strategies'. As Bartkiw (2009) notes, the triangular relationship creates a structural tendency toward underenforcement of existing standards, given the potential for confusion, conflict, or outright obfuscation concerning the division of employment law responsibilities between the client user and agency. 
Policymakers and labour law generally assumes the employer to be a unitary entity, which is not the case for agency workers' employment relations. Regardless of whether or not they work for an agency, in Quebec, workers supposedly have recourse to the CNT if their rights are violated. However, for the CNT, in such cases it is unclear who is responsible, and each situation is determined according to many different variables. This uncertain and legally complex situation acts to deter complaints: employers are protected from complaints against them and have no responsibility for workplace conditions. Besides the personal risk of job loss that workers face when grieving against their boss, the uncertainty of who is responsible further deters action. Without these protections, agency workers are often exposed to high-risk jobs without proper equipment and training. The Institut de recherché Robert-Sauvé en santé et sécurité du travail (2011) found that accident rates for agency workers were 10-11 times higher than for other workers. Another concern is that Emploi Québec, the government agency which manages social assistance and job referrals, has referred immigrant workers to agencies, thus providing a pool of immigrant labour for these kinds of jobs, notwithstanding concerns about working conditions'.

\section{The Role of Knowledge and Learning in the Struggle}

Knowledge produced by workers themselves is key to building the organizing, strategy and broader campaign work on temporary labour agencies. Besides workers' experiences of exploitation, they are often positioned to be able to shed light on agency identities and (mal)practices. Such knowledge arises in the course of outreach to agency workers at various sites, and at meetings where they can pool their experiences and discuss the conditions and possibilities for action. This is key to mapping the sector, especially given the fly-by-night nature of some agencies, and informing the direction of campaigns. Another major challenge is the ability to create effective outreach strategies and target sites of companies that contract out agency workers. The ability to effectively learn and understand the geography of the agencies could only happen through contacts in different immigrant communities, and with agency workers, especially through assemblies and organizing meetings. For example, at one meeting, an agency worker discussed how many of the agencies operate through financial services offices in certain neighbourhoods with sizeable immigrant communities. Some agencies did not pay workers directly - instead they received their weekly pay from these businesses that service working immigrants. Similarly, in the course of outreach at such locations, through building a wider contact base, agency workers noted that one way to learn which employers use agencies is to go to various metro (subway) stations at $6 \mathrm{a} . \mathrm{m}$. where workers are picked up. This insight has helped locate more employers, especially in the agricultural sector that use agency workers.

Another example of the significance of worker knowledge about agency work was that the existence of a second Dollarama warehouse was only made known to organizers through a contact who came to an organizing meeting as a result of outreach work. This process of outreach and organizing meetings has enabled the IWC and the TAWA to begin to map the web of agencies in multiple sectors such as healthcare, food processing, warehouse work, cleaning, and hospitality. Unfortunately because there is no organized existing body of knowledge that has systematically 
mapped the political economy of Montreal's agencies (and given the logistical difficulties in doing so - especially for fly-by-night operations), the day to day organizing and outreach is a key research resource that allows the TAWA and the IWC to build a clearer picture of the structure of temp work in Montreal. It also enables building a list of abusive and exploitative agencies. Another aspect of mapping the agency industry involves two other forms of coalition building. The first is a collaboration between the IWC and several unions to discuss temp agencies, pool knowledge they have from organizing sites where agency workers are employed, and share resources on broader issues of precarious work in order to put forth a series of demands on temp agencies in Quebec. The second initiative has been to try to build upon the agency workers' knowledge and the experiences of organizers to create a coherent critical narrative by forming a temp agency research committee in collaboration with engaged academics. This is a more critical and organic attempt to facilitate research combining the real experiences and knowledge of workers/organizers with the tools and resources available to academics to develop research that is relevant to organizing/campaigns.

New organizing strategies also emerge from agency workers' knowledge. One issue that the TAWA has taken up is that of holiday pay. This demand is a strategic way to ensure a living wage, without going after the employer directly. In Quebec, all workers are entitled to statutory holiday pay for holidays such as Christmas and Thanksgiving. But agency workers are usually left out of this scheme and do not receive this pay. An agency worker originally from Colombia suggested that if the fight is for agency workers to have equal rights with other workers, they should be entitled to holiday pay. So he put forward a strategy to fight for this by posting complaints and educating workers about their entitlements. In turn, the TAWA has produced flyers and framed outreach based on what the workers see as strategic demands, and effective locations and times to communicate with other agency workers.

\section{Challenges of Building Leadership}

The IWC and the TAWA have focused on building leadership among agency workers. Agency workers who organize risk being moved to another worksite. One agency worker who, with the IWC, organized a CSST workshop in the Dollarama warehouse found himself moved to a fish warehouse outside of the city by the agency which gave him increasingly difficult work until he finally quit. Yet he felt he achieved his goal, raising awareness about immigrant workers' labour rights. 'They know that they can be compensated for workplace accidents, know that they can be compensated when they're sick, so ... I'm very happy with what I did', he said. Employers use the fear of being moved from site to site as a key tool of labour discipline. This helps reduce the likelihood that a worker might file a complaint at the CNT for unjust dismissal. The agency may merely say there was no need for that worker to be at a certain enterprise and that they were needed elsewhere. This tactic creates fear amongst agency workers who hope the longer they stay at one workplace the better their chances of being hired on as a permanent worker.

Given the many barriers to organizing agency workers, creative strategies are needed. Bringing agency workers together within the TAWA can build a sense of solidarity, but at the same time different workers face different problems. For one set of workers, mainly in fly-by night 
agencies, non-payment, lack of overtime, and immigration related issues are often priorities. Many agency workers from Latin America face the threat of deportation which makes it extremely challenging to organize around workplace issues. The primary focus then is to support them in their fight for status. This can be difficult because of limited resources and capacity to do so in community labour organizations like the IWC and the TAWA in Montreal. When someone's immigration status becomes precarious and/or they are waiting for another work permit, they lose access to essential social rights like unemployment insurance, and CSST coverage. Workers supported by the IWC and the TAWA have had some success in fighting for unemployment insurance for those with expired work permits, but for the workers themselves these battles can become too emotionally draining.

\section{Campaigns}

The IWC and Au bas de l'échelle have campaigned for greater government regulation of agencies, advancing two key demands. First, agencies must have an operating license - permits should be revoked if an agency does not adhere to established regulations and work standards. Agency registration is one means of forcing them to be accountable, and ending fly-by-night operations. The second demand was co-responsibility - both agency and employer should be jointly responsible for workplace conditions. This pertains to many issues that the IWC came across regarding non-payment of wages, and health and safety concerns. A major challenge for organizing with agency workers is the lack of a mass collective workforce. When several hundred workers may work for an agency but only one person might be in each workplace, it is hard to build a common identity or a socialized workforce that can build collective action. Mobilization can also be difficult because one day a worker can work for one agency or on one worksite, and the next day another. The very nature of temp work problematizes the idea that the workplace is the main locus for labour organizing. Yet trying to build from a community organizing perspective is also extremely challenging.

How can campaigns reflect agency workers generally, but understand that within the temp agency industry there are different scales and forms of exploitation, and differences in working conditions? In Quebec, many workers who work through major agencies receive vacation pay, make deductions from their earnings, are paid regularly and with some degree of transparency; these agencies conform to labour standards and provide short term labour to major corporations. Yet such agencies arguably serve a similar function in the economy as fly-by-night agencies, where working conditions may be terrible because a worker (who may be non-status or on social assistance) is shackled to a phone waiting to see if, where and when they will work, are not properly trained and/or briefed on health and safety issues and are in a position of never being able to find steady work. These agencies build and maintain a large precarious workforce to be used by corporations and other employers. For workers in larger agencies the priorities may be concerns about discrimination and health and safety, while the latter group often focuses on basic demands, such as pay or the struggle for immigration rights and regularization. In October 2011 on the International Day for Decent Work, the IWC and Au Bas de l'echelle, supported by several unions, organized a 
rally demanding that agencies be regulated and forced to gain permits to operate from Quebec's Ministry of Labour, so that workers can take them to the CNT to file complaints for non-payment or force them to pay minimum wage. The IWC also organized a 'bad agency tour', which targeted and highlighted some of the agencies operating in Montreal including some of the fly-by-nights. This was done to allow worker-leaders who had worked for these agencies to share their stories in a more powerful way. The tour passed a Dollarama warehouse where there had been many issues of discrimination, health and safety, and job security. The tour and rally helped build strong alliances with the unions and other groups in Quebec society, yet it presented particular challenges in building real leadership amongst agency workers themselves. Those still employed by their respective agency did not want to be public. Thus the strategy was for former agency workers to speak about the specific workplace rights violations and forms of exploitation. The IWC has also worked with those workers who were more vulnerable to be more public about the general issues, in order to overcome their fear. The challenge is to be patient in helping to build agency workers' collective power to speak out about their workplace injustices.

Freeman and Gonos (2005) assert that nobody has yet created an effective legal framework that can advance the unionization and fair treatment of temp workers deployed in the workplace by exploitative temp agencies. The Toronto-based Workers Action Centre led a campaign to defend agency workers and won some gains through a recent Ontario provincial policy change, particularly through amendments relating to the scope and enforcement of the Employment Standards Act (Workers Action Centre 2007, Vosko 2010b). Some of these gains, such as the right of agency workers to be being treated like other workers under labour standards, theoretically exist in Quebec, but until co-responsibility between agency and employer is addressed, and enforced it is unlikely that workers will benefit. Vosko (2010b) critiques the Ontario law changes as inadequate. Gellatly et al. (2011: 99) criticize Ontario's individualization and privatization of the employment standards enforcement process. They argue that this shifts responsibility for enforcement from government and employers onto individual workers. This approach 'belie[s] an understanding of the complex weaving of gender, race and immigration status that characterises the uneven social relations that shape the experience of employment for many of Ontario's workers. Bartkiw (2009: 196) notes: 'To a large extent, dialogue [on regulating temp agencies] has depended upon a problem frame identifying the existence of select industry "bad apples" as the problem. This rather "low road" approach focuses on minimal outcomes, and often on remedying quite extreme or unethical behavior, such as the outright failure to pay workers at all for work performed. While some attention to this is necessary in policy reform, this frame conceals from view the increasing precarity emerging from the expansion of this form of employment unconnected to such extreme violations of basic rights'.

As temporary agency employment expands, Bartkiw (2009: 183) holds that it generates yet more precarious (non-union) employment 'that carries with it the threat of further erosion of union power and growth through labor market undercutting and the increased inability of unions to "take wages out of competition". Thus, precarious employment outcomes and restricted access to unionization become self-reinforcing. It follows that labor policy reforms to regulate temporary help agency employment that do not directly address the issue of frustrated access to unionization under 
current Canadian regimes will not likely reduce, and indeed are not at all even aimed at reducing, this structural tendency generating labor market precarity'. Similarly, Vosko (2010b: 646) argues for 'the need for creating new types of bargaining units to enable unionization, benefits beyond job tenure, precarity pay, and parity of treatment for workers regardless of the forms of employment in which they engage'.

In cooperation with other organizations working on precarious work and migration, the IWC and the TAWA began a campaign for a new Quebec law on precarious work, including demands around domestic work and access to health and safety coverage. These called for easier access to gain permanent residence and equal access to government programs for temporary foreign workers. They also call for a raise in the minimum wage to $\$ 12.00$ an hour and access to government services for all workers regardless of status. In 2013 in an open letter to Quebec's Minister of Labour, a group of agency workers demanded the right to be made permanent after three months of work at the same workplace, arguing that merely making agencies co-responsible was not enough. Thus, drawing from their own experiences and struggles, agency workers have directly put forward proposals about creating fairer labour policies and workplace conditions.

In an April 2013 town hall meeting, the IWC hosted over 60 immigrant workers from various backgrounds, who shared stories of injustice, and articulated demands instead of bureaucrats and advocacy organizations articulating these. This generated a momentum and sense of collective strength to continue and demand greater changes to Quebec labour standards to benefit precarious workers. The agency worker campaign gained some momentum with the creation of the Precarious Worker Coalition that began in response to the belief that Quebec's minister of labour would produce a bill to protect precarious workers. The TAWA initiated this coalition with the IWC, Mexicans United for Regularization, Dignidad Migrante and a public campaign with a set of demands around 'precarious work'. The coalition organized press conferences in April/May 2013, resulting in an official consultation of the leadership of the precarious worker coalition and the TAWA, on 24 May 2013, with the Ministry of Labour.

There, organizations explained concretely the issues surrounding precarious work. One agency worker said: 'I work at a company that hires 90 percent of its workers from temporary placement agencies. They are fired without cause, work without basic workplace safety requirements, are not given holiday pay and overtime, are not able to make complaints about highly dangerous workplace situations, and are still considered "temporary" workers after years of continuous employment' (Immigrant Workers Centre 2012). Since the change in provincial government in September 2012, the coalition hoped for change from the Parti Quebecois. Organizing efforts and media pressure pressured the Ministry of Employment and Social Solidarity to finally announce steps to change the laws on agencies in October 2013, although the details are rather vague. The Montreal Economic Institute (2013) a business think tank, issued a research note in response, opposing any tighter regulation of agencies, arguing that this would dissuade companies from hiring new workers, and repeating claims that agencies promote the integration of immigrant workers into the workforce. 


\section{Working With Unions on Temp Agency Exploitation of Workers and Precarity}

These organizing strategies have come at a time when the historical focus and priority of unions to organize and maintain their traditional industrial base are under sustained challenges from transformations in work, and as some (including the Quebec unions, Centrale des syndicats démocratiques (CSD), Confédération des syndicats nationaux (CSN), Centrale des syndicats du Québec (CSQ), and Fédération des travailleurs et travailleuses du Québec (FTQ) (see CSD/CSN/CSQ/FTQ 2011), think through these challenges, and acknowledge the importance of fighting for the rights of temp and non-standard workers as part of a broader strategy to defend the rights of working people. Indeed, in Quebec, a Fall 2011 joint union report on agency workers was produced in the context of a larger consultation by the Ministry of Labour on regulating temp agencies. This in turn arose from pressure from community organizations and unions working together in the Front Des Non Syndicats (FDNS), as well as the joint campaign by the IWC and Au bas de l'échelle which worked with the different labour councils during 2011 to support the campaign for agency workers as part of a broader union strategy. These actions predated the formation of the Precarious Workers Coalition, and are part of a broader strategy. The IWC's aim was for the coalition to be a process in which workers themselves can put forward their concerns about temp agencies directly to the minister, as a way to complement the existing strategy of the FDNS.

The campaign demanded that a) agencies provide a security deposit in order to reimburse all the necessary fees deducted from the agency workers; b) agencies promptly report any changes of address or administration; c) companies using agencies without a proper permit be fined; d) a principle of co-responsibility be established under Quebec's Labour Standards Act between the agencies and their client-companies, to guarantee that workers' rights and entitlements are respected; e) agencies and their client companies be held accountable to the workers they hire where pecuniary obligations (such as salaries, paid vacations, etc.) are concerned; f) to hold either the agency, the client company (or both) liable and responsible in the event that worker rights are violated (such as in instances of unjust dismissal, psychological or physical harassment, etc.); g) to enforce the labour standards, particularly relating to vacation pay, statutory holiday pay, and years of service in general; h) To ensure joint responsibility between agencies and their client-employers for CSST compensation.

The IWC and the TAWA have focused on relationship building with unions, resulting in a partnership with the CSN to work with agency workers to create activist based research from workers, labour rights campaigns and concrete support for the TAWA. This is a big first in terms of the work needed to change the face of the labour movement in Quebec and in Canada more broadly. A coalition of Quebec unions believe that the responsibility to pay for CSST coverage should rest on the client-employers rather than co-responsibility with the agencies as well. A working document formulating their position on CSST concluded the following: 'Otherwise, there will be no prevention, shared responsibility with the agency and client will restart the ball (that workers') training, safety equipment and prevention will not happen'! It is a challenge to advance these demands because to substantively address them entails placing them within the existing tripartite structure that governs the CNT between the Quebec Minister of Labour, the trade union centrals, 
and representation by employers' associations which has made it more difficult for the unions to navigate and push for progressive changes to Quebec's labour standards. In November 2013, CSN (FIM-CSN 2013) unions representing about 30,000 workers in metallurgy, chemical, quarrying, automotive, pulp and paper, sawmills, mining, and forestry across Quebec launched a campaign to demand tighter restrictions on employers being able to outsource and subcontract through agencies, undermining unionized workplaces. So, among a growing number of trade unions in Quebec, there is a realization of the broader threats posed to the future of work and workers' rights through the increasing use of agencies.

\section{Conclusion}

Global capitalism fragments labour and the lives of working people everywhere. Struggles for immigration status, dignity and justice for temporary migrant and immigrant workers are raising some of the most important challenges to capital and the state in recent years. The above examples of struggles to change the economic and social conditions of low wage agency workers in Montreal highlight the importance of engaging workers in collective self-organization. Such strategies break from orthodox post-war union organizing traditions and create community responses to labour issues. IWC support for a worker-led campaign and organization to change the structural issues of agency work has meant the creation of a TAWA that can address the different type of agency workers coming from a wide variety of experiences and ethnicities. It grapples with challenges faced by mainly newer immigrants and migrant workers in more exploitative conditions, contending with both labour problems and the regularization of status. Alongside this are workers in factories and manufacturing mainly seeking temporary work hoping to improve their skills and education. This organizing approach allows the IWC to build a more comprehensive organizing strategy, and a sense of solidarity across communities, immigration status and other experiences. Leadership development and education are central to the organizing model through labour rights workshops, media training and by allowing workers to take a leadership role in building this association. It is a hybrid model firstly, building a committee or association that can have a broad membership, secondly, dealing with policy issues at the provincial level, and thirdly, working to resolve individual grievances with agencies and employers around wage theft, health and safety, and other violations. Currently the TAWA has a core group of former and current agency workers with a monthly assembly giving a real voice and leadership from workers themselves which is different from other models of workers centres which are more policy focused. The TAWA can act like a union by formalizing the membership. The campaign has also seen workers build relationships with different community organizations and unions in order to highlight that agencies and temp work impact all workers and that for unions to be able to defend the rights of their membership means to end precarious work as a way of outsourcing decent paying work. Alongside this is an understanding that the nature of work has drastically changed and thus that the need to support such initiatives and campaigns is vital for a rebirth of the labour movement.

In Quebec, the question of finding ways to create longer term alliances and a coherent strategy differs from contexts such as Japan where the organizing of agency or contingent workers 
falls under the larger umbrella of trade unions. The IWC and the TAWA seek to create longer term alliances and a coherent strategy. Quebec unions have emphasized that the employer should be solely responsible for work conditions to clearly identify that the use of agency workers is a way to undermine unions, and allows employers to deny responsibility. They have remained important allies for the IWC's campaign through presentations at labour council meetings such as at the FTQ and CSN. In 2011, the Coalition of Labour Councils in Montreal issued a joint press release calling for the Quebec Ministry of Labour to address the demands put forth by the IWC and Au Bas de l'échelle. In 2013, the CSN began a formal partnership with the IWC to organize agency workers. These have been critical steps towards creating a real alliance between unions and community groups working towards regulating agency work, and key to understanding the importance of finding ways to fight back. The challenge remains how to organize workplaces with agency workers and workplaces employing both agency workers and unionized workers. One recent development perhaps relevant to organizing agency workers is the merger of CAW (Canadian Auto Workers union) and CEP (Communications, Energy and Paperworkers union) into a major new union, Unifor, in 2013. In the founding of Unifor there are promises of new structures to organize and mobilize workers who currently have no access to union membership: including workers without certified collective agreements, and other precarious employment. It remains to be seen exactly how this new union will meaningfully challenge workplace precarity and allow for representation of such precarious workers.

The significance of the work of activists in workers' centres and new organizations like the TAWA with temp agency workers lies not simply in organizing a smaller vulnerable workforce. These are testing grounds for new, alternative approaches or models of collective organization, and are grounded attempts to work through some of the issues, debates and tensions around the shifting centres and margins of labour market regulation and workers' struggles in Canada today. As the expansion of agency work enhances employers' ability to create a sense of fear, austerity, and denial of decent work with job security in order to generate profits, such organizing amongst a changing working class contesting their daily problems arising from precarious work is a key way to highlight local impacts of globalization. There are challenges for political coordination for organizing precarious workers across cities in Canada. This kind of precarious worker organizing is a relatively new phenomenon in Canada, by comparison to more established networks in the USA. Organizers are beginning to facilitate a conversation that could allow organizing experiences to be a way of building more effective campaigns and synergies, yet due to the relative young nature of this organizing it will take some time and resources to achieve this. The need for coordination will be crucial between the mainstream labour movement/trade unions, community-based labour organizations like the IWC, the TAWA, and other community organizations to build a broader movement against the exploitation of workers through temporary labour agencies. 


\section{ACKNOWLEDGEMENTS}

The authors acknowledge the comments and suggestions of two anonymous reviewers of this article.

\section{REFERENCES}

Henaway, M. (2012) 'Immigrant Worker Organizing in a Time of Crisis: Adapting to the New Realities of Class and Resistance', in A. Choudry, J. Hanley, and E.Shragge (eds), Organize! Building from the Local for Global Justice (pp.144-155). Oakland: PM Press.

Au bas de l'echelle (2011) Présentation au comité de travail du CCTM Sur la question des agences de placement temporaire. 14 January 2011. Available at: http://www.aubasdelechelle.ca/assets/files/nos\%20publications/memoiresavis/CCTM\%20FINAL.pdf [Accessed 9 April 2013].

Bartkiw, T.J. (2009) 'Baby Steps? Towards the Regulation of Temporary Help Agency Employment in Canada', Comparative Labor Law and Policy Journal 31(1): 163-206.

Bernier, J., Vallee, G. and Jobin, C. (2003) Les besoins de protection sociale des personnes en situation de travail non traditionnelle. Government of Quebec. Available at: http://www.travail.gouv.qc.ca/fileadmin/fichiers/Documents/normes_travail/travail_non_tra ditionnel/Introduction.pdf. [Accessed 9 April 2013]

Calugay, J., Henaway, M. and Shragge, E. (2011) 'Working Through the Loopholes Undermining Workplace Gains, One Temp Worker at a Time', Canadian Dimension 45(2): 40-43.

Casey, C. and Alach, P. (2004) “'Just a Temp?” Women, Temporary Employment and Lifestyle', Work, Employment and Society 18(3): 459-480.

Chicha, M-T. (2009) Le mirage de l'égalité. Les immigrées hautement qualifiées à Montréal. Fondation Canadienne des relations Available at : http://www.eri.umontreal.ca/evenements/documents/MTChicha_Mirage_egalite.pdf [Accessed 9 April 2013].

Choudry, A. and Henaway, M. (2012) 'Agents of Misfortune: Contextualizing Migrant and Immigrant Workers' Struggles Against Temporary Labour Recruitment Agencies', Labour, Capital and Society 45(1): 36-64.

Choudry, A., Hanley, J., Jordan, S., Shragge, E., and Stiegman, M. (2009) Fight Back: Workplace Justice for Immigrants. Halifax: Fernwood. 
Commission des normes du travail (2012) 'Sondage visant à évaluer les conditions de travail des salariés temporaires d'agences de placement de personnel et les pratiques de celles-ci. Rapport d'analyse final'. Available at: http://www.cnt.gouv.qc.ca/fileadmin/pdf/enquetes-etrecherches/Rapport-CNT79083-024_nov_2012_VF.pdf. [Accessed 9 April 2013]

Cranford, C.J., Vosko, L.F. and Zukewich, N. (2003) 'Precarious Employment in the Canadian Labour Market: A Statistical Portrait', Just Labour 3(Fall): 6-22.

Cranford, C.J. and Ladd, D. (2003) 'Community Unionism: Organising for Fair Employment in Canada', Just Labour 3(Fall): 46-59.

CSD/CSN/CSQ/FTQ (2011) Rapport des membres syndicaux du Comité sur les agences de placement temporaire. 15 September 2011.

Degiuli, F. and Kollmeyer, C. (2007) 'Bringing Gramsci Back In: Labor Control in Italy's New Temporary Help Industry', Work, Employment and Society 21(3): 497-515.

Fine, J. (2006) Worker Centers: Organizing Communities at the Edge of the Dream. Ithaca, New York and London: ILR/Cornell University Press.

FIM-CSN (2013) 'Sous-traitance et agences de placement La Fédération de l'industrie manufacturière en campagne'. Available at: http://www.csn.qc.ca/web/csn/communique//ap/COMM2013-11-22?.p_P_state=maximized\#.UppUqifjWs8. [Accessed 1 December 2013]

Forde, C. (2001) 'Temporary Arrangements: The Activities of Employment Agencies in the UK', Work, Employment and Society 15(3): 631-644.

Freeman, H. and Gonos, G. (2005) 'Regulating the Employment Sharks: Reconceptualizing the Legal Status of the Commercial Temp Agency', WorkingUSA: The Journal of Labor and Society 8: 293-314.

Fuller, S. and Vosko, L.F. (2008) 'Temporary Employment and Social Inequality in Canada: Exploring Intersections of Gender, Race and Immigration Status', Social Indicators Research 88: 31-50.

Galabuzi, G. (2006) Canada's Economic Apartheid: The Social Exclusion of Racialized Groups in the New Century. Toronto: Canadian Scholars' Press. 
Galarneau, D. (2010) 'Temporary Employment in the Downturn', Perspectives. Statistics Canada. 75-001-X. Available at: http://www.statcan.gc.ca/pub/75-001-x/2010111/pdf/11371eng.pdf [Accessed 9 April 2013]

Galarneau, D. (2005) 'Earnings of Temporary Versus Permanent Employees', Perspectives. Statistics Canada. 75-001-X. Available at: http://www.statcan.gc.ca/pub/75-001-x/10105/7761eng.pdf. [Accessed 9 July 2012]

Gellatly, M., Grundy, J., Mirchandani, K., Perry, J.A., Thomas, M. and Vosko, L. (2011) 'Modernizing Employment Standards? Efficiency, Market Regulation, and the Production of the Illegal Claimant in Ontario', The Economic and Labour Relations Review 22(2): 81-106.

Gonos, G., and Martino, M. (2011) 'Temp Agency Workers in New Jersey's Logistics Hub: The Case for a Union Hiring Hall', WorkingUSA: The Journal of Labor and Society 14(4): 499525.

Hatton, E. (2011) The Temp Economy: From Kelly Girls to Permatemps in Postwar America. Philadelphia: Temple University Press.

Immigrant Workers Centre (2012) 'Temporary Agency Workers Testimony', Migrant Voices. 2 July 2012. Available at: http://iwc-cti.org/migrant-voices-iwc-radio/. [Accessed 1 December 2013]

Institut de recherché Robert-Sauvé en santé et sécurité du travail (2011) Enquête québécoise sur des conditions de travail, d'emploi et de santé et de sécurité du travail (September). Available at: http://www.travail.gouv.qc.ca/fileadmin/fichiers/Documents/conditions_de_travail/EQCOT ESST_R-691_RAPPORT.pdf [Accessed 9 April 2013].

Kojima, S. (2010) 'When Dismissal Becomes a Business Transaction: Analysis of the Processes and Consequences of Haken-Giri Under the Global Recession', Contemporary Japan 22: 23-45.

Kundnani, A. (2007) The End of Tolerance: Racism in 21 $1^{\text {st }}$ Century Britain. London and Ann Arbor, MI: Pluto.

Lansbury, R. (2004) 'Foreword', in J. Burgess and J. Connell (eds) International Perspectives on Temporary Agency Work (pp. xvi-xviii). London: Routledge.

Latino Union of Chicago (n.d) 'About the Latino Union'. Available at: http://www.latinounion.org [Accessed 9 July 2012]

Montreal Economic Institute (2013) 'Staffing Services Industry Promotes Professional Integration of Immigrants and the Unemployed', Available at: http://www.iedm.org/46359-staffing- 
services-industry-promotes-professional-integration-of-immigrants-and-the-unemployed [Accessed 9 July 2012].

NUPGE (2007) Canada: The Land of Denied Opportunity. A Review of Canada's Temporary Foreign Workers Program. Avril). Available at: http://www.nupge.ca/files/publications/Land_of_Denied_Opportunity.pdf [Accessed 9 March 2013].

Peck, J. and Theodore, N. (2002) 'Temped Out', Economic and Industrial Democracy 23(2): 143175.

Peck, J. and Theodore, N. (1998) 'The Business of Contingent Work: Growth and Restructuring in Chicago's Temporary Employment Industry', Work Employment Society 12: 655-674.

Radio-Canada (2010) 'La jungle des agences de placement', 21 October. Available at: http://www.radio-canada.ca/emissions/enquete/2010-2011/Reportage.asp?idDoc=122495 [Accessed 9 March 2013].

Richmond, A.H. (1994) Global Apartheid: Refugees, Racism and the New World Order. Don Mills, Ontario: Oxford University Press.

Rodriguez, R.M. (2010) Migrants for Export: How the Philippine State Brokers Labor to the World. Minneapolis: Minnesota University Press.

Statistics Canada (2011) Employment Services 2009. Service Bulletin. Statistics Canada Catalogue No. 63-252-X. Available at: http://www.statcan.gc.ca/pub/63-252-x/63-252-x2011001eng.pdf [Accessed 9 March 2013].

Statistics Canada (2010) Employment Services 2008. Service Bulletin. Statistics Canada Catalogue No. 63-252-X. Available at: http://www.statcan.gc.ca/pub/63-252-x/63-252-x2010001eng.pdf [Accessed 9 April 2013].

Suzuki, A. (2008) 'Community Unions in Japan: Similarities and Differences of Region-based Labour Movements Between Japan and Other Industrialized Countries', Economic and Industrial Democracy 29(4): 492-520.

Theodore, N. and Peck, J. (2002) 'The Temporary Staffing Industry: Growth Imperatives and Limits to Contingency', Economic Geography 78(4): 463-493. 
Van Arsdale, D.G. (2013) 'The Temporary Work Revolution: The Shift From Jobs That Solve Poverty to Jobs That Make Poverty', WorkingUSA: The Journal of Labor and Society 16(March): 87-112.

Vidal and Tigges (2009) 'Temporary Employment and Strategic Staffing in the Manufacturing Sector', Industrial Relations 48(1): 55-72.

Vosko, L.F. (2010) 'A New Approach to Regulating Temporary Agency Work in Ontario or Back to the Future?', Relations Industrielles/Industrial Relations 65(4): 632-653.

Vosko, L.F. (2008) 'Temporary Work in Transnational Labor Regulation: SERCentrism and the Risk of Exacerbating Gendered Precariousness', Social Indicators Research 88: 131-145.

Vosko, L.F. (2000) Temporary Work: The Gendered Rise of a Precarious Employment Relationship. Toronto: University of Toronto Press.

Workers Action Centre (2007) Working on the Edge. Toronto: WAC.

Zaman, H. (2012) Asian Immigrants in 'Two Canadas': Racialization, Marginalization and Deregulated Work. Halifax and Winnipeg: Fernwood.

Zaman, H. (2006) Breaking the Iron Wall: Decommodification and Immigrant Women's Labor in Canada. Lanham, MD: Rowman and Littlefield.

\section{BIOGRAPHICAL NOTE}

AZIZ CHOUDRY is Assistant Professor in the Department of Integrated Studies in Education at McGill University and serves on the board of the Immigrant Workers Centre in Montreal, Quebec. [email: aziz.choudry@mcgill.ca]

MOSTAFA HENAWAY is Organizer with the Immigrant Workers Centre in Montreal, Quebec. [email: mhenaway@gmail.com] 